ks. Kazimierz Panuś

\title{
Sprawozdanie prezesa Polskiego Towarzystwa Teologicznego za rok 2007
}

Poprzednie walne zebranie Polskiego Towarzystwa Teologicznego odbyło się 27 lutego 2007 roku. Obejmowało ono część sprawozdawczą za rok 2006, udzielenie absolutorium zarządowi, wręczenie medalu Bene Merenti Polskiego Towarzystwa Teologicznego JE ks. bp. Tadeuszowi Rakoczemu, ordynariuszowi bielsko-żywieckiemu, oraz wykład prof. dr. hab. Franciszka Ziejki nt. Pieśń o ziemi polskiej.

\section{Stan Towarzystwa}

Rok 2007 był trzecim rokiem działalności zarządu wybranego 15 lutego 2005. Ukonstytuowany wówczas zarząd działał w roku sprawozdawczym w następującym składzie:

ZARZĄD

Prezes: ks. prof. zw. dr hab. Kazimierz Panuś

Wiceprezes: ks. dr hab. Józef Marecki, prof. PAT

Sekretarz: ks. mgr Kazimierz Moskała

Skarbnik: ks. dr Andrzej Mojżeszko

Bibliotekarz: ks. dr Jan Bednarczyk

Kierownik Sekcji Wydawniczej: mgr Sebastian Wojnowski

KOMISJA KONTROLUJĄCA

Przewodniczący: ks. prof. zw. dr hab. Tomasz Jelonek

Członkowie: ks. prof. dr hab. Roman Pindel, ks. dr hab. Roman Bogacz

SĄD KOLEŻEŃSKI

Przewodniczący: ks. bp dr Stefan Cichy

Członkowie: o. prof. zw. dr hab. Tomasz Dą̧bek OSB, ks. dr Teofil Siudy 
Z końcem roku 2007 Polskie Towarzystwo Teologiczne liczyło 687 członków. W roku sprawozdawczym przyjęto do towarzystwa 48 osób (w większości, bo aż 41 osób, są to członkowie nowego Oddziału Radomiu). Od ostatniego walnego zebrania do wieczności odszedł (według posiadanych informacji): dr Wacław Kolak.

Spełniając wymogi statutowe zarząd odbył w roku sprawozdawczym cztery zebrania w dniach: 25 kwietnia 2007, 25 września 2007, 28 listopada 2007, 20 lutego 2008.

Podczas pierwszego zebrania zarząd zapoznał się ze stanem przygotowań dwóch sesji naukowych Polskiego Towarzystwa Teologicznego zaplanowanych na jesień 2007 roku: pierwszej - Sześćdziesiąt lat „Ruchu Biblijnego i Liturgicznego" w stużbie odnowy biblijnej i liturgicznej w Polsce, drugiej - „Deptać po was będą jedynie wówczas, gdy zwietrzejecie” - z okazji 1600 rocznicy śmierci św. Jana Chryzostoma, połączonej z promocją książki ks. prof. Edwarda Stańka pt. Wielcy mówcy Kościoła starożytnego.

W czasie drugiego zebrania zarządu powołano nowy Oddział w Radomiu. Organizacja tego oddziału została powierzona grupie inicjatywnej, którą tworzą: ks. dr Marek Jagodziński, ks. dr Dariusz Zbigniew Skrok i ks. dr Daniel Swend. Zarząd powołał zespół pod kierownictwem ks. prof. Romana Kuligowskiego do opracowania trzyletniego programu pracy towarzystwa i określenia wspólnego tematu poszukiwań badawczych. Uznano, iż zagadnieniem tym będzie wielowymiarowo ujęty problem przebaczenia i pojednania. Kierownicy oddziałów w Sandomierzu, Kielcach, Kalwarii, Katowicach, Tarnowie i Bielsku-Białej i sekcji działających w Krakowie podzielili się z zarządem informacjami na temat planowanych spotkań naukowych i odczytów; omówiono także plany ożywienia pracy Oddziału w Rzeszowie.

Trzecie zebranie zarządu odbyło się w klasztorze Paulinów na Skałce. Na wstępie o. prof. dr hab. Andrzej Napiórkowski, rektor WSD Zakonu Paulinów i przeor klasztoru Na Skałce nakreślił tematykę Roku Wielkich Polaków i ideę Panteonu Narodowego. Wysłuchano sprawozdania z konferencji naukowej towarzystwa nt. Sześćdziesiąt lat RBL w stużbie odnowy biblijnej i liturgicznej $w$ Polsce, która odbyła się 20 listopada i przedstawiono zaproszenie na drugą konferencję naukową towarzystwa nt. „Deptać po was będą jedynie wówczas, gdy zwietrzejecie” - z okazji 1600 rocznicy śmierci św. Jana Chryzostoma. W czasie zebrania przyjęto rezygnację ks. dr. Bogdana Zbroi z funkcji kierownika Sekcji Biblijnej i powołano na to miejsce ks. dr. hab. Romana Bogacza. Ks. prof. Roman Kuligowski przedstawił rezultaty posiedzenia zespołu programowego wypracowującego trzyletni program pracy PTT. Zespół inicjatywny organizujący Oddział w Radomiu zgłosił kandydatury 41 nowych członków, którzy decy- 
zją zarządu zostali przyjęci do towarzystwa. Ustalono datę oraz program walnego zebrania (20 lutego 2008).

Czwarte przewidziane statutem zebranie zarządu odbyło się 20 lutego 2008 roku. Przyjęto rezygnację o. prof. dr. hab. Andrzeja Napiórkowskiego OSPPE z funkcji kierownika Sekcji Teologii Fundamentalnej i powołano na jego miejsce ks. dr. Józefa Morawę. Przyjęto także rezygnację ks. prof. dr. hab. Jana Górskiego z funkcji kierownika Sekcji Misjologicznej i powołano na to miejsce ks. dr. Grzegorza Wita, adiunkta w Zakładzie Misjologii i Teologii Religii Wydziału Teologicznego Uniwersytetu Śląskiego.

\section{Działalność towarzystwa}

W ramach Polskiego Towarzystwa Teologicznego działa Studium Syndonologiczne, 15 sekcji specjalistycznych i 11 oddziałów terenowych oraz Sekcja Wydawnicza prowadząca Wydawnictwo UNUM.

Studium Syndonologiczne przy Polskim Towarzystwie Teologicznym. Moderatorem studium jest ks. doc. dr hab. Jerzy Chmiel. Studium Syndonologiczne było konsultowane przez zainteresowanych naukowców (m.in. prof. Antonina Kowalska, UJ), media (TVP Historia, TVN Religia, redakcje „Skalpel i dusza”, „Brat”) oraz osoby prywatne. Członek studium mgr inż. Jerzy Dołęga-Chodasiewicz wygłosił szereg konferencji w wielu miejscowościach Polski.

SeKcja Biblijna. Kierownikiem sekcji był ks. dr Bogdan Zbroja. Sekcja liczy 39 członków. W roku sprawozdawczym sekcja nie odbyła spotkań.

SeKCjA teOlOgiI FundamentalneJ. Kierownikiem sekcji był o. prof. dr hab. Andrzej Napiórkowski OSPPE. Członkowie sekcji brali udział w ważnych wydarzeniach życia naukowego w Krakowie i poza nim. W ramach obchodu Roku Wielkich Polaków kierownik sekcji zorganizował sesję naukową nt. Humanitas. Invocatio ad magnitudinem, która odbyła się 22 marca 2007 roku.

Sekcja Historyczna. Jej pracami kieruje ks. dr hab. Józef Marecki, prof. PAT. W roku sprawozdawczym sekcja liczyła 34 członków, z których 18 systematycznie uczestniczyło w spotkaniach. Ponadto na spotkania przychodzą także inne osoby zainteresowane tematyką spotkań. W omawianym okresie sekcja odbyła sześć spotkań tematycznych, kontynuując cykl tematyczny Ludzie emigracji (rozpoczęty jeszcze w 2005 roku). Uczestnicy mogli zapoznać się z życiem i działalnością Ludwika Nabielaka (referat mgr lic. Joanny Małochy), Adama Mickiewicza (referat mgr lic. Jadwigi Hebdy), misjonarzy dominikańskich w Chinach (referat o. mgra Marka Miławickiego), emigracją wielickich górników na Bukowinę Rumuńską (referat mgr 
lic. Jadwigi Hebdy) oraz z tematem Wybitni Polacy Wielkiej Emigracji w filatelistyce polskiej (referat mgr lic. Joanny Małochy). W grudniu 2007 referatem dr Lucyny Rotter Twierdze warowne Ziemi Świętej - wspomnienia z podróży rozpoczęto nowy cykl tematyczny comiesięcznych spotkań nt. Zam$k i$, dwory i pałace. Sekcja Historyczna Polskiego Towarzystwa Teologicznego wraz z Katedrą Nauk Pomocniczych Historii i Archiwistyki Wydziału Historii Kościoła Papieskiej Akademii Teologicznej organizuje i prowadzi wykłady otwarte nt. Heraldyka i symbolika chrześcijańska. Symbolika zwierząt. Odbywają się one od października 2007 roku w każdą drugą sobotę miesiąca i gromadzą około 60 słuchaczy. Wykłady zyskały także pozytywne zainteresowanie prasy oraz wydawnictw. Wydawnictwo WAM rozpoczęło wydawanie serii płyt CD z nagranymi wykładami otwartymi oraz zamieszczonymi prezentacjami multimedialnymi. Dotychczas ukazało się pięć płyt z serii Symbolika zwierząt (nagrania na żywo w czasie wykładu), oraz pięć płyt z serii Symbolika roślin (nagrania studyjne). W 2007 roku ukazała się drukiem książka Symbolika roślin. Heraldyka i symbolika chrześcijańska, pod red. J. Mareckiego, L. Rotter, będąca pokłosiem prowadzonych w roku akademickim 2006/2007 wykładów o tym samym tytule. Członkowie zespołu włączyli się w prace dotyczące interdyscyplinarnych projektów prowadzonych przez Katedrę Nauk Pomocniczych Historii i Archiwistyki i współpracujących z nią instytucji naukowych, m.in. brali udział w konferencji naukowej Cnoty $i$ wady. społeczeństwo baroku po obu stronach Karpat zorganizowanej przez Katedrę Nauk Pomocniczych Historii i Archiwistyki (Wydział Historii Kościoła PAT) oraz Katedrę Historickych a spolocenskych vied (Greckokatolicka Teologicka Fakulta Presovskej Univerzity v Presovie). Konferencja ta miała miejsce 26 kwietnia 2007 roku (część pierwsza w Preszowie) oraz 19 maja 2007 roku (część druga w Krakowie). W obu częściach konferencji referaty wygłosili także (co zostało podkreślone) członkowie Sekcji Historycznej Polskiego Towarzystwa Teologicznego: ks. dr hab. Józef Marecki, prof. PAT, ks. dr Artur Kardaś, dr Lucyna Rotter, ks. dr Wacław Umiński, mgr lic. Joanna Małocha oraz mgr Krzysztof Gruca. Członkowie Sekcji Historycznej Polskiego Towarzystwa Teologicznego (ks. dr hab. Józef Marecki, prof. PAT, ks. dr hab. Andrzej Bruździński, ks. dr Wacław Umiński) wzięli udział także w archiwistycznej konferencji naukowej pt. Lex et praxis, która odbyła się 24 maja 2007. Materiały z obydwu sesji ukazały się drukiem w 2007 roku. Inną formą działalności sekcji było przygotowanie dwutygodniowego obozu naukowego w Grecji. Obóz ten odbył się w czerwcu 2007 roku, zyskując spore zainteresowanie. W bieżącym roku akademickim organizowany jest podobny interdyscyplinarny obóz Litwa, Łotwa, Estonia oraz Petersburg zaplanowany na przełom czerwca i lipca 2008 roku. 
W roku 2007 ukazały się trzy numery „Biuletynu Sekcji Historycznej Polskiego Towarzystwa Teologicznego". Redaktorem prowadzącym jest mgr Krzysztof Gruca. W skład zespołu redakcyjnego wchodzą także kierownik sekcji ks. dr hab. Józef Marecki, prof. PAT, o. dr Zdzisław Gogola, mgr lic. Joanna Małocha, o. mgr Marek Miławicki, mgr Mateusz Mirek. W biuletynie oprócz tekstów referatów wygłaszanych na spotkaniach Sekcji Historycznej Polskiego Towarzystwa Teologicznego zamieszczane są także fragmenty protokołów spotkań (od momentu dokumentowania pracy sekcji w 1980 roku), recenzje książek i artykułów oraz kalendarium historyczne.

Sekcja Teologir Moralnes. Sekcję prowadzi ks. dr Bogusław Mielec. W roku sprawozdawczym zorganizowano spotkanie 18 października, na którym omówiono tematykę półrocznika „Polonia Sacra”, który ukaże się w 2008 roku i będzie poświęcony zagadnieniom teologii moralnej. Kierownik sekcji wygłosił wykład nt. Wymiar duchowy zdrowia człowieka, podczas obrad XVII Europejskiego Kongresu Psychosomatyki w Krakowie pt. Promocja zdrowia - mit czy rzeczywistość: między teoria a praktyka (25-27 października) oraz wykład pt. Katolickie spojrzenie na przemoc w czasie konferencji zorganizowanej przez Międzywydziałowy Instytut Ekumenii i Dialogu (20 listopada).

SeKcja Homiletyczna. Przewodniczącym sekcji jest ks. prof. zw. dr hab. Kazimierz Panuś. W roku sprawozdawczym Sekcja Homiletyczna uczciła 1600. rocznicę śmierci św. Jana Chryzostoma, włączając się w organizację konferencji naukowej, której motywem przewodnim był cytat tego wielkiego kaznodziei z Homilii XV, 5 do Ewangelii św. Mateusza: „Deptać po was będą jedynie wówczas, gdy zwietrzejecie...”. W trakcie konferencji, która odbyła się 29 listopada 2007 w auli Wyższego Seminarium Duchownego Archidiecezji Krakowskiej przy ul. Podzamcze 8 w Krakowie, kierownik sekcji wygłosił referat nt. Aktualność kaznodziejska Ojców Kościoła w przepowiadaniu Ewangelii.

Sekcja Socjologiczno-Pastoralna. Pracami sekcji kieruje ks. dr Stefan Dobrzanowski. W roku sprawozdawczym sekcja zorganizowała konferencję, na której wygłoszono dwa referaty: Współczesna polska rodzina a kultura masowa (prof. Franciszek Adamski) oraz Religijność i kultura współczesnych Chin (ks. dr Stefan Dobrzanowski).

Sekcja Sztuki Sakralnej. Kierownikiem sekcji jest ks. prof. dr hab. Zdzisław Kliś. Sekcja Sztuki Sakralnej opracowała w 2007 roku materiały z konferencji naukowej pt. Z dziejów kościoła Franciszkanów w Krakowie. W listopadzie 2007 roku zorganizowana została konferencja naukowa poświęcona kościołowi św. Floriana w Krakowie. Materiały pokonferencyjne zostaną opublikowane przez Wydawnictwo UNUM. 
SeKcJa Filozoficzna. Kierownikiem sekcji jest o. dr Piotr Jordan Śliwiński OFMCap. Sekcja nie przedstawiła sprawozdania.

SeKcJA TeOlogi Życia WewnętrZnego. Kierownikiem sekcji jest ks. dr Jan Nowak. 23 czerwca 2007 roku sekcja zorganizowała w Krakowie-Łagiewnikach sympozjum poświęcone Słudze Bożemu księdzu Władysławowi Bukowińskiemu. Sylwetkę duchową kapłana ukazał o. prof. Dominik Wider OCD, o procesie kanonizacyjnym w archidiecezji krakowskiej mówił ks. dr Andrzej Scąber, a drogę kapłańską Sługi Bożego przedstawił ks. dr Jan Nowak. Z dużym zaciekawieniem przyjęto wypowiedzi świadków, którzy spotkali ks. Władysława, zwłaszcza prof. Jerzego Węgierskierskiego, współwięźnia ks. Władysława w łagrze w Dżezkazganie. Sekcja duchowości także w ramach swoich spotkań przygotowała Statut Stowarzyszenia im. ks. Władysława Bukowińskiego „Ocalenie”. Jego celem jest troska o kult sługi Bożego ks. Władysława Bukowińskiego, pomoc w prowadzeniu procesu beatyfikacyjnego, modlitwa za osoby duchowne oraz duchowa pomoc katolikom na Wschodzie. Oprócz sympozjum sekcja zorganizowała jeszcze kilka spotkań. Jedno z nich nt. Święci realizują miłość Chrystusa odbyło się w ramach ruchu „Ku Cywilizacji Miłości” (26 listopada).

Sekcja Pedagogiczno-Katechetyczna. Kierownikiem sekcji jest ks. dr hab. Janusz Mastalski, prof. PAT. W roku 2007 sekcja przyjęła 2 nowych członków oraz włączyła się w organizację kilku sympozjów. I tak w czerwcu 2007 roku została zorganizowana (we współpracy z Papieską Akademią Teologiczną, Akademią Pedagogiczną w Krakowie oraz Wyższą Szkołą Zawodową im. Bogdana Jańskiego) ogólnopolska konferencja pt. Rodzina $w$ kontekście wspótczesnych problemów wychowania. We wrześniu został zorganizowany cykl wykładów i szkoleń dla samorządowców i nauczycieli pt. Wymiary wspótpracy rodziców i nauczycieli w procesie wychowania. W październiku sekcja uczestniczyła w organizacji XVII Europejskiego Kongresu Psychosomatyki pt. Promocja zdrowia - mit czy rzeczywistość: między teoria a praktyka. Dodatkowo sekcja zorganizowała spotkanie studyjne mające charakter panelu, na którym podjęto tematykę problemów zogniskowanych wokół tzw. „karty lizbońskiej” oraz aksjologicznych wymiarów wychowania w szkole XXI wieku.

SeKcja Dogmatyczna. Kierownikiem sekcji jest ks. dr hab. Jan Żelazny. Sekcja (wraz ze studentami Wydziału Historii Kościoła PAT) zorganizowała 2 spotkania dyskusyjne. Członkowie sekcji włączyli się w prace nad przygotowaniem konferencji naukowej towarzystwa nt. „Deptać po was będą jedynie wówczas, gdy zwietrzejecie" - z okazji 1600 rocznicy śmierci św. Jana Chryzostoma. W jej trakcie kierownik sekcji wygłosił referat Pedagogiczne podejście do odbiorcy. Rozważania w oparciu o Homilie św. 
Jana Chryzostoma do Listu do Hebrajczyków. Materiały z konferencji naukowej zostaną opublikowane w „Ruchu Biblijnym i Liturgicznym” 2 (2008).

Sekcja Misjologiczna. Kierownikiem był ks. dr hab. Jan Górski, prof. UŚ. Sekcja nie przedstawiła sprawozdania.

Sekcja Prawa Kanonicznego. Kierownikiem sekcji jest ks. dr Józef Rapacz. W roku sprawozdawczym zorganizowano 2 spotkania: 27 kwietnia nt. procesu małżeńskiego z referatami: Tytuły nieważności małżenstwa (ks. dr Józef Rapacz) oraz Poszczególne etapy w postępowaniu o orzeczenie nieważności matżeństwa (ks. dr Stanisław Molendys) oraz 26 października nt. nieważnego zawarcia małżeństwa z referatami: Niezdolność do podjęcia istotnych obowiązów matżeńskich (ks. dr Józef Rapacz) oraz Pismo powodowe o stwierdzenie nieważności matżeństwa (ks. dr Stanisław Molendys). Spotkania zorganizowano przy parafii św. Jadwigi Królowej w Krakowie.

Sexcja Liturgiczna. Sekcję prowadzi ks. mgr lic. Stanisław Mieszczak SCJ. Sekcja nie przedstawiła sprawozdania.

Polskie Towarzystwo Teologiczne w Krakowie działa także poprzez swoje oddziały terenowe. I tak:

Oddzial w Katowicach. Pracami oddziału kieruje ks. dr Andrzej Nowicki. W roku sprawozdawczym członkowie Oddziału w Katowicach zorganizowali dwa spotkania. Pierwsze z nich miało miejsce 17 maja podczas konferencji poświęconej problematyce dialogu międzyreligijnego. Referat wprowadzający pt. Spotkanie jako element konstytutywny dialogu" wygłosił ks. dr Andrzej Nowicki. Następnie uczestnicy spotkania rozpoczęli dyskusję nad treścią problemu zawartego w tytule referatu. Członkowie Oddziału w Katowicach byli także wraz ze Śląskim Seminarium Duchownym współorganizatorami Dni duchowości, które odbyły się w dniach 25-26 września 2007 w Wyższym Śląskim Seminarium Duchownym w Katowicach pod hasłem: Słowo Boże w życiu $i$ misji Kościoła. W pierwszym dniu w sesji przedpołudniowej swoje referaty wygłosili: o. prof. Fabio Ciardi OMI reprezentujący Papieski Uniwersytet Salezjański w Rzymie (Słowo Boże w historii Kościoła) oraz ks. dr Jan Miczyński z Katolickiego Uniwersytetu Lubelskiego ( Słowo Boże jako oręż w walce duchowej). W sesji popołudniowej po przerwie, podczas której uczestnicy sympozjum uczestniczyli we wspólnej Eucharystii, głos zabrali następujący prelegenci: ks. dr hab. Jan Machniak, prof. PAT (Szukać Chrystusa w wiernym rozważaniu słowa Bożego), oraz ks. dr Wacław Borek z Uniwersytetu Opolskiego (Jak przemieniać stowo prawdy w czyn? - Lectio divina do Jk 1, 19-27). W drugim dniu swoją refleksją w aspekcie wyżej określonego tematu podzielił się ponownie o. prof. Fabio Ciardi (Stowo dające życie. Słowo, którym się $\dot{z} y j e)$. Następnie głos zabrał ks. prof. zw. dr hab. Henryk Wejman reprezen- 
tujący Uniwersytet Szczeciński (Maryja wzorem chrześcijanina, który stucha, medytuje słowo Boże i nim żyje). Po każdym z wykładów miała miejsce ożywiona dyskusja, w której uczestniczyli członkowie Oddziału w Katowicach, obecni na spotkaniu studenci Wydziału Teologicznego Uniwersytetu Śląskiego oraz alumni Wyższego Śląskiego Seminarium Duchownego w Katowicach. Zebrania Oddziału w Katowicach odbywają się najczęściej w gmachu Wyższego Śląskiego Seminarium Duchownego. W spotkaniach bierze także udział zainteresowane grono studentów teologii.

Oddzial w Częstochowie. Pracami oddziału kieruje ks. dr Jerzy Bielecki. W roku sprawozdawczym odbyły się 4 zebrania zarządu oddziału i zorganizowano dwa posiedzenia naukowe: w maju z referatem ks. dr. Teofila Siudego pt. Maryjna wiara $i$ kult w ujęciu kard. Josepha Ratzingera - papie$\dot{z} a$ Benedykta XVI i w listopadzie z referatem ks. dra Jacka Marcińca Metanaukowy kontekst metodologii Galileusza.

Oddziat w Przemyślu. Pracami oddziału kieruje ks. prof. dr hab. Marian Wolicki. W okresie sprawozdawczym odbyły się 3 spotkania: 11 maja - z referatem ks. dra hab. Kazimierza Bełcha, prof. UKSW, nt. Duszpasterstwo migrantów; 13 czerwca - z referatem ks. dr. hab. Jana Twardego nt. Wpływ kaznodziei na wole stuchaczy oraz 23 listopada 2007 - z referatem ks. dr. hab. Jana Twardego nt. Motywacja w kaznodziejstwie.

Oddzial w Kalwari Zebrzydowskiej. Kieruje nim o. dr Romuald Kośla OFM. W okresie sprawozdawczym Oddział w Kalwarii Zebrzydowskiej działający przy Wyższym Seminarium Duchownym Bernardynów zorganizował trzy spotkania: 16 lutego - dr Roman Mikołajczyk wygłosił referat nt. Z teologii rodziny: O odpowiedzialnym rodzicielskie $i$ naturalnym planowaniu rodziny. 23 maja w Krakowie w klasztorze Bernardynów odbyła się sesja naukowa z racji kanonizacji bł. Szymona z Lipnicy pt. Świętość zrodzona z miłości z następującymi referatami: Znajdawniejszych dziejów Lipnicy Murowanej (prof. Feliks Kiryk), Wpływidei kierunku obserwanckiego Zakonu Braci Mniejszych na życie Szymona z Lipnicy (o. dr Aleksander Krzysztof Sitnik OFM), Święty Szymon z Lipnicy - mistrz życia franciszkańskiego, apostot i patron zadżumionych. Wybrane zagadnienia z ikonografii bernardyńskiej w Polsce (o. dr Efrem Andrzej Obruśnik OFM), Duchowość św. Szymona z Lipnicy (o. prof. dr hab. Jerzy Wiesław Gogola OCD), Droga do kanonizacji św. Szymona z Lipnicy (o. dr hab. Stefan Ryłko CRL), Dzięki św. Szymonowi z Lipnicy św. Kazimierz Królewicz żyt według duchowości franciszkańskiej (o. dr Grzegorz Wiśniowski OFM). Trzecie spotkanie oddziału 10 listopada połączone było z inauguracją roku akademickiego. W jego ramach o. dr hab. Jarosław Kupczak OP wygłosił referat na temat: O dobru w ujęciu Jana Pawła II. 
Oddzią w Tuchowie. Kieruje nim o. dr Marek Kotyński CSsR. Oddział tuchowski działa w Wyższym Seminarium Duchownym Redemptorystów przy Studium Filozofii w Krakowie (ul. Zamojskiego 56) oraz przy Studium Teologii w Tuchowie (ul. Wysoka 1).

OdDZIAE w KielCACH. Kierownikiem oddziału jest ks. prof. dr hab. Roman Kuligowski. Prace oddziału kieleckiego w roku sprawozdawczym skoncentrowały się nad przygotowaniem publikacji Wyobraźnia miłosierdzia oraz sesji naukowej Miłosierdzie w teologii i literaturze. Książka pt. Wyobraźnia miłosierdzia pod red. ks. Pawła Borto, ks. Romana Kuligowskiego, ks. Zbigniewa Trzaskowskiego i ks. Andrzeja Żądło została wydana przez Wydawnictwo UNUM. Stanowi ona wspólne przedsięwzięcie teologów, literaturoznawców i językoznawców skierowane do wszystkich zainteresowanych kulturą religijną. Natomiast sesja naukowa Miłosierdzie $w$ teologii i literaturze odbyła się 26 października. Zorganizowana została wspólnymi siłami oddziału kieleckiego i Instytutu Filologii Polskiej Akademii Świętokrzyskiej. W Auli im. Bpa Czesława Kaczmarka w Wyższym Seminarium Duchownym w Kielcach zgromadziło się ponad trzystu słuchaczy, w większości studentów filologii polskiej i teologii. W trakcie sesji wygłoszono następujące referaty: Jezus uosobieniem miłosierdzia Ojca $w$ świetle Ewangelii (ks. prof. dr hab. Józef Kudasiewicz, KUL), Miłosierdzie a etyka walki zbrojnej (dr Grażyna Legutko, AŚ), Liturgia katolicka w stużbie „wyobraźni miłosierdzia” (ks. dr hab. Andrzej Żądło, UŚ), Ewangeliczne mitosierdzie wpisane $w$ ethos pisarza (ks. dr Zbigniew Trzaskowski, AŚ), Motyw miłosierdzia Bożego w utworach wybranych autorów staropolskich (dr Marzena Wydrych-Gawrylak, AŚ), Istota miłosierdzia wg encykliki „Dives in misericordia” (ks. dr Paweł Borto, WSD). Kierownik oddziału dokonał rekapitulacji głównych wątków sesji. W zgodnej opinii prelegentów i pozostałych uczestników należała ona do udanych, co zachęca do prac mad przygotowaniem drugiej sesji naukowej o podobnym interdyscyplinarnym charakterze.

OdDZIAŁ w SANDOMIERZU. Kierownikiem oddziału działającego przy Instytucie Teologicznym im. bł. Wincentego Kadłubka w Sandomierzu jest ks. prof. dr hab. Jan Zimny. W okresie sprawozdawczym zorganizowano 8 konferencji naukowych: II Sandomierskie Dni Cyrylometodiańskie - międzynarodowa sesja naukowa (14 lutego), Szkolnictwo katolickie w myśli Kościoła. Konferencja w 30-lecie dokumentu La scuola cattolica (Stalowa Wola, 19 marca), Wypalenie zawodowe pracowników stużb społecznych (Stalowa Wola, 9 października), Miłość jako fundament $i$ cel działalności edukacyjnej $w$ perspektywie przemian cywilizacyjnych i kulturowych - sesja trzydniowa (Stalowa Wola, 16-18 października), Pedagogika katolic- 
ka-szanse $i$ wyzwania (Sandomierz, 14 listopada), Stulecie periodyku diecezjalnego „Kronika Diecezji Sandomierskiej” - sesja dwudniowa (Sandomierz, 15-16 listopada), Standardy wykonywania wtadzy publicznej (Stalowa Wola, 26 listopada) oraz Edukacja zdrowotna w naukach medycznych i społecznych (Stalowa Wola, 12 grudnia).

Oprócz udziału w konferencjach naukowych organizowanych w Sandomierzu i Stalowej Woli członkowie oddziału sandomierskiego uczestniczyli również w następujących konferencjach w kraju i zagranicą: ks. prof. dr hab. Jan Zimny: Specyfika europejskiego nauczyciela XXI wieku (Kijów, 14-18 maja), Wpływ inteligencji chrześcijańskiej na życie społeczne w Europie Środkowej (Budapeszt, 8-10 czerwca), Program operacyjny rozwoju Polski wschodniej 2007-2013 (Rzeszów, 11 października), Uznawalność wykształcenia i kwalifikacji zdobytych za granica w kontekście wejścia Polski do Unii Europejskiej (Warszawa, 19 października), Podstawowe czynniki osobowości: problemy i perspektywy (Chmielnicki, 24-26 października), Polskie dzieci na tułaczym szlaku 1939-1950 (Warszawa, 8 listopada), Problematyka zjawisk spoteczno-patologicznych $w$ środowisku szkolnym - stan, prewencja, rozwiąania (Rużomberok, 16 listopada) oraz Nauczyciel wobec szans i zagrożeń edukacyjnych XXI wieku (Łódź, 19-20 listopada); ks. dr Roman Sieroń: 45. Sympozjum Stowarzyszenia Biblistów Polskich (Pelplin, 18-20 września), Sześćdziesiąt lat „Ruchu Biblijnego i Liturgicznego" w stużbie odnowy biblijnej i liturgicznej w Polsce (Kraków, 20 listopada); ks. prof. dr hab. Jan Zimny, ks. dr Roman Sieroń i ks. mgr lic. Eugeniusz Nycz: Szanse rozwoju Wydziału Zamiejscowego Nauk o Społeczeństwie KUL w Stalowej Woli poprzez różne wymiary działalności nowo utworzonej fundacji „Campus” (Stalowa Wola, 29 grudnia); ks. dr Roman Sieroń, ks. dr Adam Kończak: Polskie Dzieło Biblijne im. Jana Pawta II w obliczu zbliżające go się Synodu Biskupów o Słowie Bożym w misji i życiu Kościoła (Warszawa, 26 stycznia). W prace oddziału żywo angażuje się biskup sandomierski prof. dr hab. Andrzej Dzięga. Członkowie oddziału sandomierskiego prowadzili także wzmożoną działalność wydawniczą, czego owocem jest 8 pozycji książkowych wydanych w roku sprawozdawczym.

OdDZIAE W TARNOWIE. Kierownikiem oddziału jest ks. dr hab. Janusz Królikowski, prof. PAT. W roku sprawozdawczym oddział poświęcił swoje cykliczne spotkania opracowaniu założeń podręczników w tarnowskiej serii Academika. Dotychczasowa formuła okazuje się już niewystarczająca, dlatego zaszła potrzeba jej udoskonalenia. Efektem podjętych dyskusji stały się pierwsze tomy wydane w nowej wersji przez wydawnictwo Biblos. Podjęto ponadto refleksję teologiczną nad wizytą papieża Jana Pawła II w Tarnowie w roku 1987, by w ten sposób uczcić jej dwudziestą rocznicę. Owocem podjętych badań jest przygotowana okolicznościowa publikacja, która została złożona do 
druku. We współpracy z wydawnictwem Biblos zainicjowano serię wydawniczą Theologumena, której dwa pierwsze tomy ukazały się w 2007 roku. Zamieszczono w nich akta dwóch sympozjów zorganizowanych przez oddział w 2006 roku. Przygotowano do druku dwa kolejne tomy. Jeden z nich obejmuje efekty prac dotyczących teologii królowania Chrystusa, które podjął tarnowski oddział w 2006 i 2007 roku. We współpracy z Agencją Wydawniczą „Promocja” w Mielcu podjęto inicjatywę wydawania nowego rocznika „Studia Regionalne" o tematyce historycznej i kulturowej dotyczącej tamtejszego regionu. Pierwszy tom ukaże się w końcu marca.

Oddziat w Rzeszowie. Kierownikiem oddziału jest ks. dr hab. Andrzej Garbarz. 22 października w auli Instytutu Jana Pawła II w Rzeszowie pod przewodnictwem bpa Edwarda Białogłowskiego odbyło się spotkanie założycielskie. Przybyło 21 osób. Znaczącym osiągnięciem było wydanie dwutomowej księgi pamiątkowej Ecclesiae, patriae et domini serviens dedykowanej ordynariuszowi diecezji ks. bp. Kazimierzowi Górnemu z okazji 15-lecia istnienia diecezji. Pozycja ta jest dziełem wspólnym Instytutu i Oddziału Rzeszowskiego Towarzystwa Teologicznego.

OdDZIAŁ w BIELSKU-BiAŁEJ. Kierownikiem oddziału jest ks. prof. dr hab. Tadeusz Borutka. Oddział istnieje od 26 września 2006 roku i liczy aktualnie 41 członków. W roku sprawozdawczym odbyły się dwa spotkania: 19 stycznia - spotkanie opłatkowe dla członków Polskiego Towarzystwa Teologicznego i środowiska akademickiego Podbeskidzia z udziałem ks. bpa Tadeusza Rakoczego oraz 20 listopada. Wykład nt. Encyklika papieża Piusa XII „Mediator Dei” jako podtoże soborowej odnowy liturgii wygłosił ks. dr hab. Erwin Mateja (Uniwersytet Opolski). Członkowie Oddziału w Bielsku-Białej wzięli również udział w odbywającej się dniach od 14 do 15 listopada 2007 roku sesji naukowej na temat: Dialog. Spotkanie z Innym organizowanej wspólnie z Akademią Techniczno-Humanistyczną w Bielsku-Białej.

OddZią w RADOMIU. Kierownikiem oddziału jest ks. dr Dariusz Zbigniew Skrok. Oddział został powołany 25 września 2007 roku i znajduje się w fazie organizacji. Należy podkreślić, iż mimo tak krótkiego czasu istnienia liczy już 41 członków.

\section{Uwagi końcowe}

Do najważniejszych dokonań zarządu Polskiego Towarzystwa Teologicznego w roku sprawozdawczym należy zaliczyć powstanie nowego oddziału terenowego w Radomiu. Dzięki wysiłkom kierownika oddziału rzeszowskiego ks. dr hab. Andrzeja Garbarza ożywia się też działalność towarzystwa w tym mieście. 
Ważnym wydarzeniem dla Polskiego Towarzystwa Teologicznego było zorganizowanie i przeprowadzenie dwóch konferencji naukowych. W pierwszej z nich nt. Sześćdziesiąt lat „Ruchu Biblijnego i Liturgicznego” w stużbie odnowy biblijnej i liturgicznej w Polsce, PTT przypomniało wielki wkład swego czasopisma w odnowę biblijną i liturgiczną w Polsce. W drugiej nt. „Deptać po was będą jedynie wówczas, gdy zwietrzejecie" - z okazji 1600. rocznicy śmierci św. Jana Chryzostoma uwrażliwiono na szereg problemów patrystycznych i kaznodziejskich istotnych dla współczesnego życia Kościoła w Polsce.

Z uznaniem należy podkreślić ożywioną działalność oddziałów kieleckiego i sandomierskiego oraz Sekcji Historycznej, która w roku sprawozdawczym nie tylko prowadziła ożywioną działalność, ale wydawała pismo „Biuletyn Sekcji Historycznej”.

W roku sprawozdawczym upowszechniła się też wiedza o naszym towarzystwie. Należy również przyznać, iż organizowanie spotkań sekcyjnych niektórych sekcji nie zawsze spotykało się z szerokim odzewem, a posiedzenia nie gromadziły wielu osób.

Polskie Towarzystwo Teologiczne jest kościelną osobą prawną o zasięgu ogólnopolskim. Stąd też zarząd na ręce kard. Stanisława Dziwisza oraz księży biskupów obecnych na walnym zebraniu składa serdeczne podziękowanie Konferencji Episkopatu Polski za troskę władz kościelnych o rozwój towarzystwa.

Zarząd dziękuje również wszystkim aktywnym członkom Towarzystwa, którzy mimo wielorakich trudności czynią wszystko, aby działalność towarzystwa była kontynuowana i służyła dalszemu ubogaceniu polskiej myśli teologicznej.

Kraków

KS. KAZIMIERZ PANUŚ 